dyed fabrics at the time when the coal-tar colours were discovered. Their value as dyestuffs was without question, the world's yearly consumption of indigo alone, at that time, representing some $4,000,000 l$.

It must also be remembered that it was not the question alone of the commercial production of the dye in competition with the natural product which was sought, because this must have appeared a totally impracticable problem in those early days. It was rather the search for the reason why alizarine was a mordant dye and why indigo was a vat-dye which was the incentive to research, because when these facts were discovered other substances having similar properties could be prepared. The attack in every case.followed the usual lines. In the first instance, the structure of alizarine (the mordant dyestuff of the madder root) was revealed by analysis, when Baeyer found that it gave anthracene on distillation with zinc. Its synthesis from the anthracene of coal-tar followed in the next year, being effected almost simultaneously by Graebe and Liebemann in Germany and by Perkin in England. In this case the preparation was so simple and the raw material so easily obtained that the natural madder industry was rapidly killed. The determination of the formula and synthesis of alizarine showed the $\mathrm{CO} \mathrm{OH}$

particular grouping, namely; $/>\mathrm{OH}$, on which mordant dyeing depended. Hence the preparation of a large number of analogues of varying shades of colour followed.

The determination of the structure of indigo took longer, and occupied Baeyer at Munich some eighteen years. In this case the colour was synthesised and manufactured on a commercial scale three years before its structure was determined, because, as sometimes happens, a reaction, the course of which was then unknown, led to the formation of the dye. Here, again, the determination of structure showed that the property of vat-dyeing depended on the presence of $\mathrm{CO}$

the grouping $-\mathrm{C}=\mathrm{C}$, and in consequence, whereas blue indigo was the only known member of its class in 1890 , at the present day every shade of colour is represented in this particularly fast series.

Finally, at the beginning of the present century, the accidental discovery of indanthrene by Bohr placed on the market the first member of a series of vat-dyes, which constitutes without question the fastest series of colouring matters hitherto prepared. Practically all shades of colours are represented, the principle of dyeing being essentially the same as that of indigo.

Before the War we relied mainly on Germany for the production of our dyestuffs, and, what was still more serious, we left to them the research work on which the production of new dyestuffs depended. Dyestuff chemistry is merely a branch of organic chemistry, which includes also the preparation of organic chemical substances used in a variety of industries essential in peace and war. The possession of a dyestuff industry implies, therefore, the possession of a band of trained organic chemists and, what is more important, the possession of university and university college laboratories, where organic chemists can be adequately trained in methods of research. As a member of the Dyestuffs Development Committee, it has been my good fortune within the past six months to visit all the dye-producing factories operating in Great Britain, and I have been struck with the very real success which has attended the efforts of the past five years to establish the industry. If we had merely reached the level of excellence attained in Germany before the War, the fact would have been very creditable, but we have done more than this, and in several cases, notably in the production of a new indanthrene green, we have already drawn ahead; a position, it is to be hoped, we shall not again lose.

\title{
Some Geographical Aspects of the British Empire Exhibition.
}

THE British Empire Exhibition at Wembley, in 1 the north-west outskirts of London, strikes at once a note on the Empire as a unit. From the Palace of Engineering, with its sense of the fullness of the metallurgical industries of Britain, across the way to the Palace of Industry, almost crowded out with the multifarious products of Britain's factories, one gathers an impression of diversity as shown by fountain-pens and gramophones in contrast with big guns and giant railway engines, of high quality from the silks and laces to the coach-work on the motor cars, of stability from the various types of safe and strong room to the giant turbines; and, withal, there is a feeling of much energy crowded into a tiny space. Visit may succeed visit to these two great palaces, the main monument to the occupations of Britons at home, and yet their innermost recesses, their by-ways, and their out-of-the-way corners would not all be explored; it would appear that the visitor is left deliberately with few indications of the wealth of British products here housed, for each visit brings to light something previously missed and leaves the thought that there is yet something more to find.
The British Isles are thus presented as a crowded hive of industry, and this impression is intensified when one penetrates below the surface. Mannequin parades, exhibits of machine processes in cotton, paper, and so forth, are co-operative efforts; they are not labelled as the work of one firm or as, necessarily, the product of one district; they are specimens of Britons' work. The student of geography who wishes to emphasise or correct his book-lore is driven to much mental effort to analyse the contents of these great buildings, to sort out the products, say, of the Black Country and to localise the various elements of industrial Britain. Except in a few instances, mainly in the food section, the visitor is not asked to buy, and the exhibit is not primarily designed as an advertisement; in this respect the student would penetrate deeper and more easily into the mysteries of British manufactures at one of the annual trade shows, such as the British Industries Fair or the Motor Show. Of course, customers from overseas can get into touch with manufacturers, but the trading element, the business of selling the goods, is kept in the background; here is primarily an exhibit of what

$$
\text { NO. } 2856 \text {, VOL. I I4] }
$$


can be produced by the British Isles as the chief congeries of factories in the Empire.

Over against the impression of works jostling with works to pour out useful commodities for use throughout the Empire lies the first, and the dominant, feeling which is aroused by the pavilions devoted to Australia, Canada, and New Zealand. Each of these suggests life in the open spaces where there is room and to spare for all; a largeness and perspective about the exhibits strikes immediately the right note. In the same spirit the divisions of the country are obscured; it is intentional that the visitor should have to make an effort to discover whether he is examining the products of New South Wales or Victoria, of the Canterbury Plains or Taranaki. Take the simple matter of apples; the housewife at home is concerned with the quality of the fruit, not with the location of the orchards; in each pavilion she may see and buy fine specimens, and she carries away the notion that the greengrocer may supply Canadian, Australian, or New Zealand apples; she may see adjacent pictures of Canadian orchards and only after diligent inquiry learn that one picture shows life in the Annapolis Valley and the other a scene in British Columbia, places 3000 miles apart. Similarly, butter is seen in refrigerating chambers in Canada and New Zealand, sheep are sheared in Australia, timber of all kinds, undressed, dressed, worked into furniture, is shown from all three countries. Canada invites attention to her magnificent water supply with its uses for power installations; Australia indicates by a model farm the irrigation of an arid area.

In these pavilions, as elsewhere, the complete exhibit is a concrete demonstration of the products of each country as a whole, and the best guide to the pavilion is probably a list from a Blue-book of the products of each land; there is little attempt to indicate relative importance; each country says simply, This is what we can do, this is our contribution to the Empire's needs, will the Empire make use of our efforts?

In this regard the main part of each show deals with a few primary products, meat, wool, ores, timber, but a similar note is struck regarding the factory. products of the chief towns. Emphasis is not laid upon the work.of Toronto in competition with Montreal or of Melbourne rather than Sydney, but upon the one main fact that Canada and Australia can make house furniture, boots and shoes, apparel, and so on, of a quality which exceeds expectation. Canada is not merely a farmer's land, a land of the backwoods and prairie; Australia is more than a home for the squatter or the bushranger. Even the prairies or the Australian back-blocks are no longer the scene of primitive human labour, that of the hands; the prairie quarter section is depicted near a railway with a convenient elevator against which a moving train stops until the grain has poured into the truck; Australian sheep are sheared and Australian cows are milked by machinery.

Leaving the spacious lands the visitor reaches, in turn, India, Burma, and Ceylon, and again receives the right impression of crowds and ceaseless activity, but with this difference, that the activity is concerned, on the whole, with products each of small import. So there comes before him the questions of cotton, tea, and rice. In the Palace of Industry a cinema has told him the story of cotton, and machinery has whirred and clanged as the fabrics were made before his eyes; here are the raw material, the native weaver, and the native product all in readiness for the contrast to be obtained from a subsequent visit to the African pavilions to find experimental cotton growing and other native looms at work.

Here, and more forcibly at Hong-Kong, the spirit of the Eastern bazaar is displayed; here is the peddling of home-made products and the country's curios. Rightly, perhaps, the primitive elements of Indian life are hidden except in relation to the ameliorative work of the missions, India being presented rather from the point of view of the business and needs of the Empire than from that of a true perspective picture of what Indian life is like in all its degrees.

Thus the visitor passes to the smaller sections of the Empire, the best guide, as always, a Blue-book list of products, cocoa, kola, palm oil, rubber, and so on, for the Gold Coast, for example, and in addition, both within and without the pavilions, a skilled attempt to produce the essential atmosphere of the colony with native craftsmen, native scenes, and the products of domestic industries. The tour so far has been a continuous descent in the scale from the English locomotive and the Canadian motor-car to the Indian shawl and the West Coast brass or silver bowl with a hammered pattern, from a Doulton vase to a piece of African pottery. Diamonds, gold, ostrich feathers in South Africa, fish, paper-making, and the Newfoundland $\operatorname{dog}$ in Newfoundland, oranges in Palestine, an interesting historical exhibit in Malta, whaling and sealing in the Falklands, copra in Fiji, are but a tithe of the things to see in the remaining pavilions.

Imperial communications are focussed in an interesting model in the Government pavilion, but they are constantly to the fore elsewhere, either in the separate pavilions of the Canadian railways, or as specimens of railway carriages or ship's quarters or as model steamers or models of docks and wharves in the several Imperial units. The would-be settler has every inducement to find out all he wishes to know about any land which attracts him, and Imperial comparisons are possible under the guidance of the Department of Overseas Trade.

Health questions in the Empire are dealt with in the Government pavilion in a section which deserves to become more popular.

In every corner the visitor is carried away to some distant land, from every detail he gathers a suggestion which leads cumulatively to a notion of what each name, Malaya, British Guiana, East Africa, implies, and even a scamper of merely one day's visit through the several pavilions gives reality to these far-off homes of Britons overseas, and the wise visitor probably pauses and looks back over the pavilion itself to grasp the message it conveys ; the colour scheme of West Africa, the caribou and bison of Canada, the Maori whare and Samoan hut, the pillars at the entrance with the pagodas of Burma, the Indian pavilion as a whole, all contribute to the general effect, which is intensified by the slow passage over Old London Bridge with the views from either end, the old heart of the Mother City brooding over the wonders brought into being by her sons, the Empire builders.

$$
\text { NO. } 2856 \text {, VOL. I I } 4]
$$

